\title{
BLOOD GILLS OF SIMULIUM PICTIPES
}

\author{
THOMAS J. HEADLEE
}

IT is a well known fact that during larval life many aquatic insects possess gills. These have been regarded as thin transparent extensions of the body wall, which may or may not contain tracheæ. In one type of insect gill, the organ is abundantly sup-. plied with tracheæ, and the evident function of the organ is the purification of the air contained in the tracheæ. Such a gill is known as a tracheal gill. In the other type, known as a blood gill, it is blood within the gill that is purified.

Whether there exist in pterygote insects true blood gills in the narrow application of this definition, is still an open question. Such organs have been described as present in many groups, notably in the larvæ of Trichoptera and Diptera. Those interested in the general discussion of the subject may find a concise but excellent résumé of the work done in Kolbe ('93) and Packard ('98).

Few of these so called blood gills have, however, been subjected to morphological examination. It is the purpose of the present paper to discuss from this view-point these structures of the larva. of Simulium pictipes Hagen, a species of black-fly abundant in the streams about Ithaca, New York, but I shall first consider some of their grosser variations which appear in other species of Simulium.

Projecting from the anus on the dorsal side of the last abdominal segment, there may be seen in the living black-fly larva, three white, soft, curved filaments, which are in some species simple and in others branched. As long ago as 1823, Verdat called attention to these structures and gave good figures of the lateral and dorsal views of the larva of Simulium sericium Fries, showing three unbranched gills arising from the dorsal side of the posterior end of the body. His figures have been copied by a number of writers. Graber ('77) figured the unbranched gills of the larval Simulium columbaczense Schönb. C. V. Riley ('87) figured two types- 
the unbranched filaments of Simulium meridionale Riley, and the branched structures of Simulium pecuarum Riley. Curiously enough, although figuring the gills in their correct position, Riley states in his general discussion that they occur on the under side of the body - a statement made by Osten Sacken sixteen years earlier, although even he contradicted himself by copying the figures of Verdat. In addition to these there have been figured, by Meinert ('86), who refers to them as anal papillæ, the unbranched gills of Simulium ornatum Meigen, by Townsend ('93) the branched type of a species of Simulium from the Grand Cañon of Colorado, by Lugger ('96) the simple type of Simulium tribulatum Lugger, and by Johannsen (:03) the unbranched type of Simulium hirtipes Fries.

Miall and Hammond seem to have been the first to call attention to the fact that these structures are retractile into the rectum, a fact which may be verified by study of living, or better, sectioned, specimens.

Most writers agree that these filaments are gills but there is a divergence of opinion regarding the method by which they function. Planchon ('44), Osten Sacken ('70), Riley, Townsend, and Comstock ('95) considered them as tracheal gills, Osten Sacken, Riley, and Osborn even stating that they connect with large internal tracheæ. Miall and Hammond, and Johannsen, on the other hand, regarded them as blood gills and without tracheæ. Such is the condition of our knowledge concerning this mode of respiration of Simulium larvæ. No connected work on the finer anatomy of their gills has been published. Such mention of the subject as occurs is confined to the gross anatomy and is scattered through accounts of life histories and descriptions of species.

In undertaking a more detailed study of the subject as exemplified in Simulium pictipes, both living and sectioned larvæ have been examined. For the study of the tracheæ found in the region of the gills it is very helpful to examine living larvæ, as in fixed material the lack of air in these passages makes it hard to see their finer branches. Most of the histological details were, of course, gained through a study of sections. To prepare these, larvæ were killed and fixed in Flemming's mixture, in hot and cold absolute alcohol, and in hot and cold Gilson's fluid. The hot alcohol and 
hot Gilson's fluid were about equally successful. The material killed in the former cut easily but showed some shrinkage, while that prepared with the latter cut less easily and showed less shrinkage. The Flemming material cut so poorly that the preparations made from it were of little value. By staining on the slide with Gage's hæmatoxylin and orange $G$, the tissues were well differentiated.

In the living larva the gills are white, soft, and translucent, and

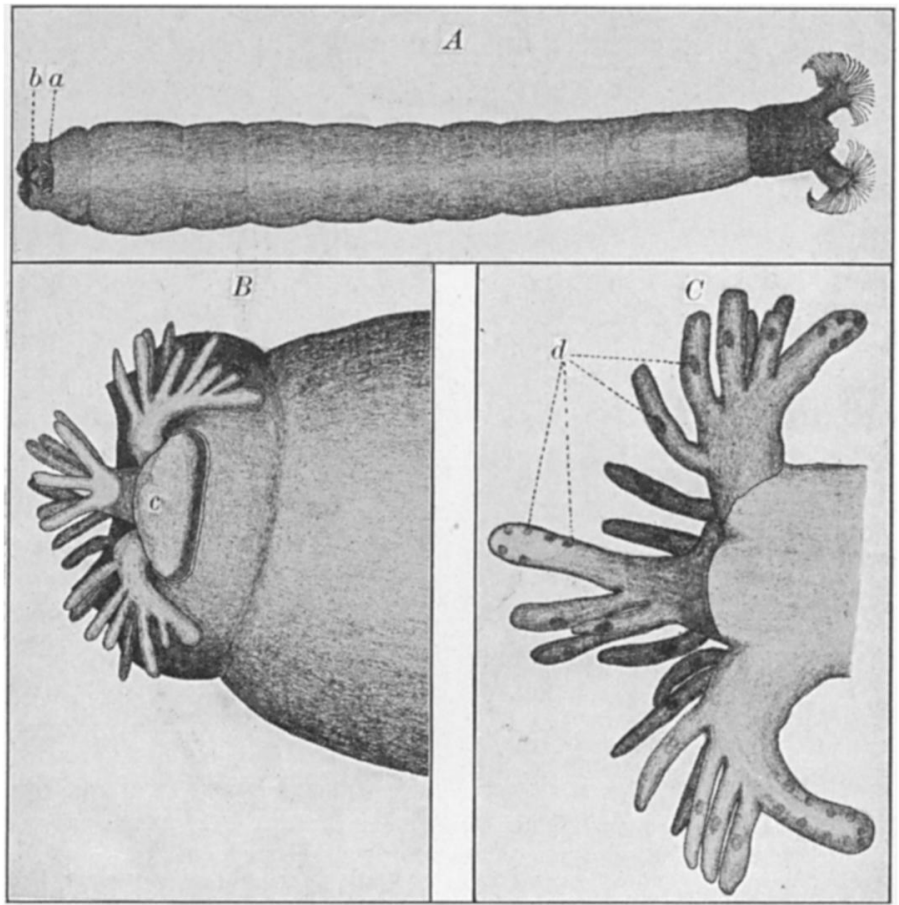

Fig. 1.- A. Dorsal view of the larva of Simulium pictipes, $(\times 8)$. B. Dorsal view of the posterior end of the larva showing the gills projecting from the anus, $(X 13)$. C. Projected gills, showing the main filaments, finger-like branches, and some of the nuclei in each, $(X 57)$. $a$, anus with slightly projecting gills; $b$, strongly chitinized $\mathrm{X}$-shaped piece; $c$, dorsal wall of the rectum which has been everted and covers the bases of the gills; $d$, nuclei of main and branch filaments.

appear on the dorsal side of the last abdominal segment, just anterior to a dark, strongly chitinized, X-shaped piece (Fig. 1, A, a, b). They are projections of the ventral wall of the rectum and lie, when retracted, completely within the rectal cavity (Fig. 2, A). 
They consist of three main filaments arising from the ventral rectal wall, each about $400 \mu$ long and $120 \mu$ wide at the base, tapering to $75 \mu$ near the middle and to $60 \mu$ at the distal end, and each furnished with many finger-like branches arising from their lateral and ventral walls (see Fig. 1, B.).

As might be expected from their morphological relationship,

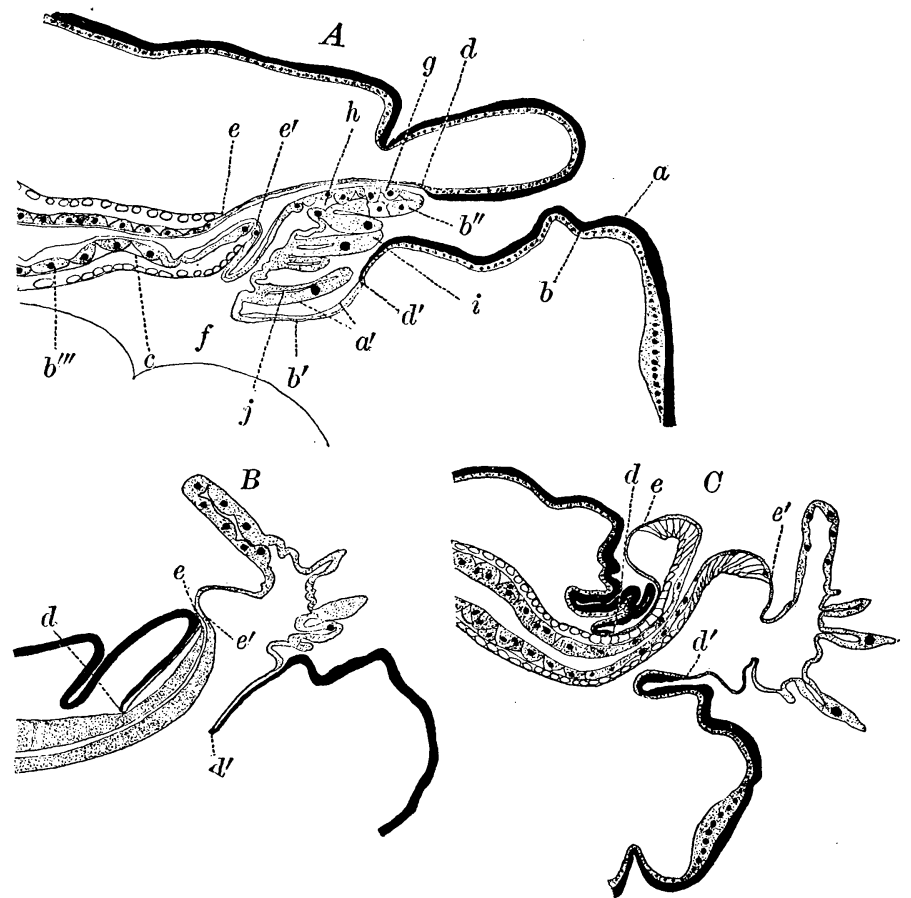

FIG. 2.- A. Sagittal section of the posterior end of the larva showing the gill within the rectum and showing the relation of its component layers to those of the rectum, $(\times 52)$. B. Similar section showing the gill projecting, $(\times 52)$. C. Similar section showing the gill projecting to its fullest extent. $(\times 53) . \quad a$, cuticle of body wall; $a^{\prime}$, intima of rectum and gill; $b$, hypodermis; $b^{\prime}$, rectal epithelium; $b^{\prime \prime}$, gill epithelium; $b^{\prime \prime \prime}$, normal hind-intestinal epithelium; $c$, basement membrane; $d$, and $d^{\prime}$, transition from body wall to rectal layers on the dorsal and ventral sides respectively ; $e$ and $e^{\prime}$, transition from rectal to normal hind-intestinal layers on the dorsal and ventral sides respectively; $f$, body cavity; $g$, main filament; $h$, cavity of main filament; $i$, finger-like branch; $j$, cavity of branch.

the gills are composed of the same three layers as is the rectum; the intima on the surface, the epithelium next, and the basement membrane adhering closely to the epithelium and lining the gill cavity. The intima is exceedingly thin, perfectly transparent and 
without apparent structure. The epithelium is a layer varying in thickness from $5 \mu$ to $18 \mu$, composed of large, distinct, somewhat flattened cells well filled with cytoplasm, and containing each a single large nucleus, in which the nucleolus and chromatin markings are very distinct. The chromatin occurs throughout the nucleus but is distributed a little more thickly around the periphery (Fig. 3, A and C). The basement membrane is very thin and much like that found under the hypodermis (Fig. 2, A).

At the point of union between the body wall and the rectum there is a marked decrease in the thickness of the layers, the intima and epithelium being much more delicate than the cuticle and hypodermis; and this condition is continued to a point some distance cephalad of the gill (Fig. 2, A) except that the epithelium of the gills is thicker than that of the chamber containing them. The basement membrane continues from the hypodermis through the gill without noticeable change.

The cells lining the distal end of the main filament are slightly larger than those at
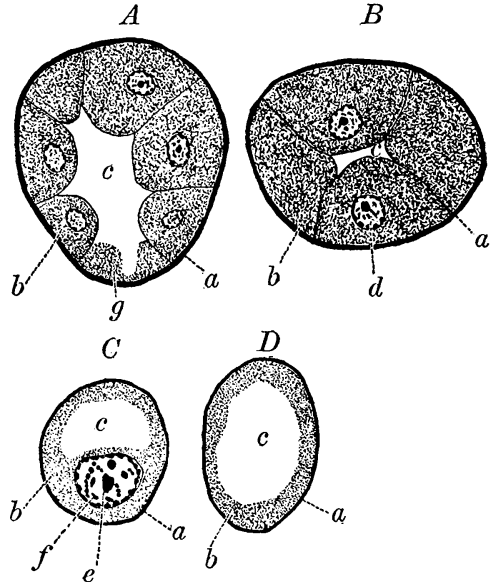

FIG. 3.- A. Cross section of a main filament taken at a point midway between the base and distal end, $(\times 255)$. B. Similar section taken near distal end, $(\times 255)$. C. Cross section of a finger-like branch taken in the region of the nucleus, $(X 255)$. D. Similar section taken between nucleus and base, $(\times 255)$. $a$, intima; $b$, epithelium; $c$, cavities of both branch and main filaments; $d$, nucleus; $e$, nucleolus; $f$. chromatin granule; $g$, base of a finger-like branch. the base (Fig. 3, A, B). Each finger-like branch is composed of a single large cell, the base of which helps to form the wall of the main filament (Figs. 2, A, and $3, \mathrm{~A})$. These branch cells are much larger than the main filament cells and contain larger nuclei, in which the chromatin particles more distinctly appear (Fig. 3, A, B, C). The nuclei are generally located near the middle in the cells of both the branches and the main filaments, but in the branches they are often nearer one side than the other. The nucleus, covered by a thin layer of 
cytoplasm, occasionally projects into the cavity which penetrates the branch. The gill cavities occupy the main filaments, penetrate the branches, and communicate freely with the body cavity at the base of the gills. Found within these chambers are masses of slender tracheæ and as their presence in these organs strongly suggests that they do not function wholly as blood gills, I shall discuss them in detail.

During the larger part of the time I spent in this work, I believed tracheæ to be wanting in these gills, but masses of fine tube-like structures which appeared in the sections excited doubt. Having secured some living larvæ, I cut off, after many unsuccessful attempts, a projected gill. This being quickly mounted and examined with a $\frac{1}{6}$-inch objective and 1-inch ocular, there appeared reaching up into the gill cavities, masses of fine tracheal tubes filled with air. While they enter all parts of the basal opening, they are thickest in four main bands, two entering the central lobe and one each of the lateral lobes. This collection into bands might result from mechanical causes but, as a similar arrangement appeared in the sectioned material, it seems probable that it is the natural condition. The tubes are small, about $1 \mu$ in diameter, of uniform size, and rarely branching unless in contact with the wall. They penetrate all parts of the gill cavity, and generally one and frequently two slender tracheæ lying close to the wall penetrate to the very tip of a unicellular branch. When viewed with a $\frac{1}{12}$ oilimmersion lens there may be seen in mounted and stained sections, given off from these tracheæ which lie close to the wall, fine branches penetrating the protoplasm. These air vessels gradually decrease in size as they approach the ends of the cavities. Just below the base of the gills they average $2 \mu$ in diameter, half way up the main lobe they are about $1 \mu$, and near the ends of the finger-like branches they have decreased to a diameter of $0.8 \mu$. These measurements were taken while the tubes were filled with air.

The tracheæ branch very rarely in the gill cavity and in such cases as I have observed, the resulting branches were each about as large as their common parent. I have seen no tracheal trunks in the gill cavities, although they appear below in the body cavity. and in many cases the slender tracheæ penetrating the gills have been traced to them. 
While it has not been possible to see the actual blood movement in the projected gills, the abundance of blood-mass which appears in the sections in all parts of their cavities clearly demonstrates its presence there.

The gills may be projected or retracted at the will of the animal. When out, the middle filament projects dorso-cephalad, the side filaments dorso-latero-cephalad, and all the branches are thrown free into the swiftly flowing water which is the normal habitat of the animal (Fig. 1, B). The projection of the gills includes not only a movement of the organs themselves but also of the rectum. The usual amount of movement is shown in Fig. 2, A and B. Points $e$ and $e^{\prime}$ represent the beginning of the normal intestinal epithelium on the dorsal and ventral sides respectively, while $d$ and $d^{\prime}$ represent the beginning of the body wall on the same respective sides. In Fig. 2, A, the gills are retracted, while in Fig. 2, B, they are projected as much as the healthy animal usually protrudes. them. In Fig. 2, B, $e$ and $e^{\prime}$ have moved to the dorsal surface of the body, while $d$ and $d^{\prime}$ have retained almost the same position. Sometimes, however, the living animal may project the gills to the extent illustrated in Fig. 2, C, and when killed in hot alcohol generally does so. This protrusion differs from that of the ventral sacs in the Thysanura, where the sac is simply turned wrong side out, for these are projected without being everted.

These gills are almost if not completely withdrawn when the animal is moving, and project freely only when it is fastened by its caudal sucker. They are rarely quiet when projecting but are usually moving a little way in or out.

I have found no muscular apparatus by the action of which the gills could be projected, but have been able to make them protrude by pressure exerted progressively from in front backward, and, as I have found the blood-mass in sections of protruded gills, it seems only reasonable to conclude that the gills are pushed out by an inflow of blood under such pressure as might be exerted by a contraction of the body muscles.

The gills are retracted by striated muscles which do not, so far as I can determine, penetrate their cavities. At least eight muscle bands are inserted on or near the bases of the gills, and each plays some part in the retraction of those organs. To aid my descrip- 
tion of these muscles, I have made a diagram (Fig. 4) to show their position in the body of the animal, and have'designated those of the left side in the order of their insertion passing from left to right, by the letters $a, b, c$, and $d$, and the corresponding ones of the right side, also in the order of their insertion passing from right to left, by the letters $a^{\prime}, b^{\prime}, c^{\prime}$, and $d^{\prime}$. Muscle $a$, which has a diameter of about $35 \mu$ just before branching, is as large as any of the gill retractors. It is fastened to the basal region of the left gill by three branches. One is inserted in the lateral, another in the dorso-lateral, and a third in the ventro-lateral aspect of the

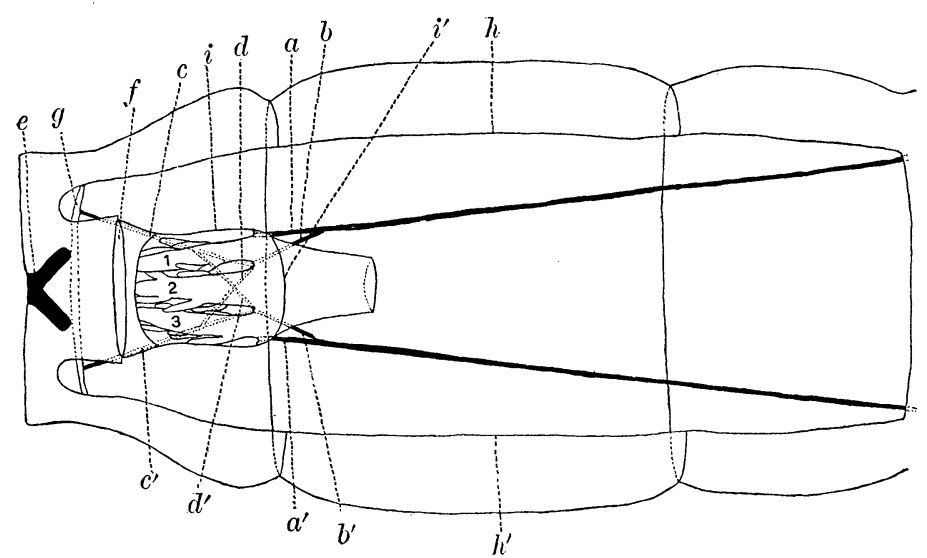

FIg. 4.- Diagram of the muscles which retract the gills. The dorsal wall of the body is cut away along lines $h$ and $h^{\prime}$ and a part of the dorsal wall of the rectum is cut away along lines $i$ and $i^{\prime}$. The ventral wall of the body is exposed by the first and the floor of the rectum upon which the gills lie by the second operation. 1,2 , and 3 , the left, central, and right gills; $e$, strongly chitinized $\mathrm{X}$-shaped piece; $f$, anal opening; $g$, infolding of the body wall lying on the abdominal floor just cephalad of the caudal sucker.

left gill base. Of these, the second is both the largest and most clearly inserted. These branches pass cephalad and quickly fuse to form $a$, which passes dorso-cephalad and slightly laterad until it finally fastens to the ventral aspect of the dorsal wall of the abdomen. After the junction of the three branches forming $a$ and before it reaches its point of origin, it is joined by muscle $b$ and later by a large muscle band from the anal region. Muscle. $b$, which is also a large conspicuous band of about $27 \mu$ diameter, is inserted in the ventral aspect of the tissue between the left and 
central gill bases. From thence it passes dorso-cephalad and laterad until it joins muscle $a$. Muscle $c$, a smaller, yet plainly marked band of about $12 \mu$ diameter, is inserted in the gill at the same point as $b$, and extends ventro-caudad and slightly laterad until it reaches the floor of the abdomen where it attaches to an infolding of the body wall. This infolding extends transversely across the abdominal floor just cephalad of the caudal sucker. Muscle $d$, the diameter of which is slightly less than that of $c$, is inserted just mesad of $c$ and extends ventro-caudad and mesad until it fuses with muscle $c^{\prime}$ of the right side.

As the muscles of the right side correspond to those of the left they require no separate discussion.

When the gills are pushed out, the muscles are drawn with the base into the everted part of the rectum, and when they contract the gills are pulled back to their place inside.

The presence of functional tracheæ in their cavities points to the conclusion that these organs must, in some degree, function as tracheal gills; for, if they act only as blood gills, the epithelial cells, inasmuch as the oxygen before reaching the blood must pass through their substance, would need no tracheation. But the comparatively small number and size of the tracheæ supplied to the gills, together with the undoubted presence of blood in their cavities, render untenable the hypothesis that they function wholly as tracheal gills.

In the light of this work it is evident that, except in a remote morphological sense, not all gills are extensions of the body wall but that some are borne by the rectum, and it is also evident that not all insect gills act wholly either as tracheal or as blood gills, but that some function as both.

In conclusion, I wish to acknowledge my indebtedness to Professor J. H. Comstock in whose laboratory this research was prosecuted, and to Dr. William A. Riley whose constant and kindly criticism has been invaluable. 


\section{BIBLIOGRAPHY}

Comstock, J. H.

'95. Manual for the Study of Insects, p. 452.

Graber.

'77. Die Insekten, Zweiter Theil, p. 516.

HAASE, E.

'89. Die Abdominalanhänge der Insekten. Morph. Jahrb, vol. 15, pp. 331-435.

HAGEN, $\mathrm{H}$.

'79. Simulium pictipes. Proc. Boston Soc. Nat. Hist., vol. 20, p. 306. JoHANNSEN, O. A.

:03. Aquatic Nematocerous Diptera. N. Y. State Mus. Bull., no. 68. Kolbe, H. J.

'93. Einführung in die Kenntniss der Insekten.

KolLAR.

'48. Ueber die Entstehung der Gollubatzer Mücken. Sitzb. Akad. Wien, vol. 1, p. 92, pls. 1-3.

Meinert, Fr.

'86. De eucephale Myggelarver.

Miall and Hammond.

:00. The Structure and Life History of the Harlequin Fly, p. 83 and elsewhere.

MÜLLER, F.

'88. Larven von Mücken und Haarfluglern mit zweierlei abwechselnd chätigen Athemwerzeugen. Ent. Nachr., vol. 14, pp. 273-277.

Osborn, H.

'96. Insects Affecting Domestic Animals. U. S. Dept. Agr., Div. Ent., bull. 5, n. s., pp. 31-58.

Osten Sacken, C. R.

70. On the Transformations of Simulium. Amer. Ent., vol. 2, p. 229 (with references).

Oudemans, J. T.

'87. Beiträge zur kenntniss der Thysanura und Collembola.

Packard, A. S.

'98. A Text-book of Entomology, p. 475.

Planchon, J. E.

'44. Histoire d'une larve aquatique du genre Simulium. Montpellier. RILEY, C. V.

'87. Simulium pecuarum and meridionale. U. S. Com. Agr. Rept. for 1886-1887, pp. 492-517, pls. 6-8. 
Schiodte, J. C.

72. De Metamorphosi Eleuthetatorum Observationes, Pars 6. Scrtryk af Naturh. Tidsskr., vol. 8, p. 202.

Thienemann, A.

:03. Analkiemen bei den Larven von Glossosoma boltoni Curt, und' einigen Hydropsychiden. Zoöl. Anz., vol. 27, pp. 125-129.

Townsend, C. H. T.

'93. On a Species of Simulium from Grand Cañon of Colorado. Trans. Amer. Ent. Soc., vol. 20, pp. 45-48, text-fig. 5.

Verdat, G. J.

'23. Mémoire pour servir à l'histoire des Simulies. Naturw. Anz. d. schweiz. Ges., vol. 5, p. 65. Translated into German in Thon's: Archiv, vol. 2, pp. 66-69, with figures.

WESTWOOD.

'48. The Water-cress Fly. Gardener's Chronicle, p. 204. 